\title{
Determination of Heavy Metals in Surface Water, Sediments and Planktons at the Junction of Multiple Rivers (Punjnad Headworks) and Their Impact on Human Health
}

\section{Saima Naz}

The Government Sadiq College Women University Bahawalpur

\section{Borhan Mansouri}

Kermanshah University of Medical Sciences

Ahmad Manan Mustafa Chatha

The Islamia university of Bahawalpur

\section{Qudrat Ullah}

The University of Agriculture, Dera Ismail Khan

Zain UI Abadeen ( $\nabla$ drzain47@gmail.com )

University of Agriculture Faisalabad

\section{Muhammad Zahoor Khan}

The university of Agriculture, Dera Ismail Khan

\section{Adnan Khan}

Chinese academy of agricultural sciences

\section{Saba Saeed}

Government Sadiq college women university, Bahawalpur

\section{Rayees Ahmad Bhat}

Kurukshetra University

\section{Research Article}

Keywords: Aquatic toxicity, heavy metals, sediment, plankton, health risk

Posted Date: October 18th, 2021

DOI: https://doi.org/10.21203/rs.3.rs-982004/v1

License: (c) (i) This work is licensed under a Creative Commons Attribution 4.0 International License. 


\title{
1 Determination of heavy metals in surface water, sediments and
}

2 planktons at the junction of multiple rivers (Punjnad Headworks)

3 and their impact on human health

4

\author{
Saima Naz ${ }^{1}$, Borhan Mansouri ${ }^{2}$, Ahmad Manan Mustafa Chatha ${ }^{3}$, Qudrat Ullah $^{4 *}$, Zain Ul \\ Abadeen $^{5 *}$, Muhammad Zahoor Khan ${ }^{4}$, Adnan Khan ${ }^{6}$, Saba Saeed ${ }^{1}$, Rayees Ahmad Bhat ${ }^{7}$ \\ ${ }^{1}$ Department of Zoology, The Government Sadiq College Women University, Bahawalpur, Pakistan; \\ Email: Saima.naz@gscwu.edu.pk Email: ssaba5306@gmail.com \\ ${ }^{2}$ Substance Abuse Prevention Research Center, Health Institute, Kermanshah University of Medical \\ Sciences, Kermanshah, Iran; Email: borhanmansouri@yahoo.com \\ ${ }^{3}$ Department of Entomology, University College of Agriculture and Environmental Sciences, The \\ Islamia University of Bahawalpur, Pakistan; Email: manan.chatha@iub.edu.pk
}

${ }^{4}$ Faculty of Veterinary and Animal Sciences, The University of Agriculture, Dera Ismail Khan, Pakistan. Email: qudratmahsud@gmail.com Email: zahoorkhattak91@yahoo.com

${ }^{5}$ Department of Pathology, Faculty of Veterinary Science, University of Agriculture, Faisalabad, Pakistan; Email: drzain47@gmail.com

${ }^{6}$ Shenzhen Branch, Guangdong Laboratory for Lingnan Modern Agriculture, Genome Analysis Laboratory of the Ministry of Agriculture, Agriculture Genomics Institute at Shenzhen, Chinese Academy of Agricultural Sciences, Shenzhen 518000, China. Email: dr.adnan93@ @au.edu.cn

${ }^{7}$ Department of Zoology, Kurukshetra University, Kurukshetra, India. Email: bhatrayess8@gmail.com

\section{*Corresponding authors}

Dr. Qudrat Ullah

Email: qudratmahsud@gmail.com
Zain Ul Abadeen

Email: drzain47@gmail.com 
28 Abstract:

29 This study was conducted to calculate the burden of heavy metals i.e., aluminium (Al), arsenic 30 (As), barium $(\mathrm{Ba})$ and lead $(\mathrm{Pb})$ in the river water of Punjnad Headworks, Bahawalpur, 31 Pakistan. For this purpose, samples were collected from surface water, bed sediments and 32 planktons during autumn, winter and spring seasons (September 2018 to May 2019). The results showed that in surface water $\mathrm{Pb}$ concentration was highest $\left(453.87 \mathrm{mg} \mathrm{L}^{-1}\right)$, while in sediments and plankton, Al concentration was highest $\left(370.24 \mu \mathrm{g} \mathrm{g}^{-1}\right.$ and $315.05 \mu \mathrm{g} \mathrm{g}^{-1}$, respectively). A significant difference $(p<0.000)$ in metal concentrations was found among surface water, bed sediments and plankton at different sampling stations during various seasons. However, findings of this study showed no adverse effects of heavy metal concentrations on human health. This study provided better understanding of various pollutants and their concentrations in water sources at the studied location.

40 Keywords: Aquatic toxicity, heavy metals, sediment, plankton, health risk 


\section{$41 \quad$ Highlights}

42

43

- In this study, presence of heavy metals including $\mathrm{Al}, \mathrm{As}, \mathrm{Ba}$ and $\mathrm{Pb}$ in surface water, sediments and plankton at rivers junction was determined.

- Samples were obtained from three different stations of the rivers' junction during autumn, winter, and spring seasons.

- $\mathrm{Pb}$ concentration was highest in surface water, while in sediments and plankton, $\mathrm{Al}$ concentration was highest.

- Although different concentrations of heavy metals were found in collected samples, however no statistically adverse effect were found in human health. 
Heavy metals generally enter into the aquatic environment through natural or anthropogenic phenomenon. Among these the most important are atmospheric depositions, soil erosion, weathering of the geological matrix and the anthropogenic sources like runoffs, leachates, urban sewer, agricultural production, industrial and urban activities (Ferreira et al. 2020; Zeng et al. 2020). Pollution of the aquatic ecosystem i.e., lake, rivers stream, estuaries and bays by heavy metals has become a global concern and has raised health related issues for human and other living organisms because of their acute and chronic toxicity, bioaccumulation throughout the food chain, non-biodegradability and persistence for longer period of time (Li et al. 2020; Ustaoğlu and Islam 2020; Naz et al. 2020). The Agency for Toxic Substances and Disease Registry (ATSDR) has listed As and $\mathrm{Pb}$ as the most hazardous heavy metals based on their toxicity, frequency as well as chances for human exposure, while $\mathrm{Ba}$ and $\mathrm{Al}$ are ranked at 136 and 183 position, respectively (ATSDR 2019). Lead $(\mathrm{Pb})$ is a non-essential metal that has no known biological function and exhibits extreme toxicity. Exposure to $\mathrm{Pb}$ for longer period has adverse effects on reproductive efficiency, circulatory and central nervous systems as well as chronic renal insufficiency (Wani et al. 2015). Arsenic (As) is also one of the most toxic elements having adverse effects on human health including liver damage, skin lesions, diabetes, cardiopulmonary outcomes, hypertension, breast and bladder cancer (Khan et al. 2020; Mitra et al. 2020). Arsenic and $\mathrm{Pb}$ are among the most dominant pollutants found in different fresh water sources of Pakistan (Bhatti et al. 2019; Mahfooz et al. 2019). Along with As and Pb, toxic levels of $\mathrm{Al}$ and $\mathrm{Ba}$ were also found in industrial and river water samples in Punjab, Pakistan (Mahfooz et al. 2019). Presence of Ba in polluted water, seafood and freshwater fishes has been reported to affect different physiological systems in human beings including cardiovascular system, renal system, and nervous system (Kravchenko et al. 2014). Aluminium 
patients suffering from Alzheimer's disease and neuroinflammation (Huat et al. 2019). Looking into the importance of heavy metals in different water resources, it is essential to estimate the level of heavy metals in aquatic environment to monitor the quality of the ecosystem for exposure to contaminants and their potential impact on human health and other aquatic organisms.

Heavy metal levels in the aquatic environment are usually determined by assayed of their levels in sediment, water and aquatic organism samples. The main pathway of metal input in aquatic ecosystems is the transport of sediments from upstream to downstream along the river basin, especially during high flow (Dutton et al. 2018). Investigation on sediments for monitoring long-term metal deposition in the ecosystem is more suitable than that of water (MacDonald et al. 2000). Different metals from industrial and agricultural water run-off drain into rivers and canals, ultimately accumulating in sediments (Omwene et al. 2018; Naz et al. 2020). Although, sediments diminish the bioavailability of pollutants by letting them settle down at the bottom of the water source, however, metalloids and heavy metals are trapped in the sediment in various chemical forms. Hence, heavy metals becomes the potential hazard for downstream water sources as these build-up upstream (Heise and Förstner 2007; Islam et al. 2015; Schleiss et al. 2016).

The zooplankton and phytoplankton both serve as a biomarker of metal pollution in water body owing to their capability of accumulating heavy metals in high concentrations (Javed 2006; Yuan et al. 2020). The water quality of a riverine system is largely affected by the direct discharge of nearby industrial effluents (Islam and Mostafa 2018) and concurrently, by the sustainable management of the water sources through implementing legislative policies and effective political control (Howes et al. 2017). Heavy metals were detected in higher concentration in plankton near the riverine water body's coastal area due to the discharge of 
untreated waste products of sewerage treatment plants into the rivers (Rezai and Yusoff 2011; Robin et al. 2012).

The higher discharge of numerous metallic compounds into the rivers of Pakistan has adversely affected the freshwater ecosystem (Qadri and Faiq 2020). Being junction of multiple rivers, Punjnad Headworks receives a variety of pollutants from different rivers. Major pollutants include agricultural, domestic and industrial wastes from different cities e.g., Gujarat, Faisalabad, Jhang, Multan etc., which drain out their waste from textile, dying, petrochemical, hosiery, oil refineries, sugar and flour mills, distilleries, tannery industries, rubbers and plastics into the river ecosystem of the Punjnad headworks (Ali et al. 2013; Eqani et al. 2011; Hanif et al. 2016). As the Punjnad headworks was an unexploited region to evaluate heavy metals contamination in a junction of different water sources, therefore, the current study was designed to assess heavy metal concentration and to conduct multivariate relationships among water, sediments and plankton for the flow of heavy metals at three different stations of Punjnad headworks. Based on the results an assessment of the health risk to humans was carried out using some risk assessment parameters.

\section{Materials and Methods}

\section{Study area}

The Punjnad Headworks is located about $99 \mathrm{~m}$ above the sea level. The average annual rainfall, average annual temperature and annual average relative humidity $(\% \mathrm{RH})$ were recorded as 3.56 $\mathrm{mm}, 29.49^{\circ} \mathrm{C}$ and $27.64 \%$, respectively. Surface water, bed sediments and plankton samples were collected from three different locations of Punjnad Headworks during three seasons (autumn, winter, and spring). The sampling stations were visited monthly for the study period. In this study, samples was collected from September 2018 to May 2019 from three stations (Station 1: $29^{\circ} 20^{\prime} 31.8^{\prime \prime} \mathrm{N} 71^{\circ} 00^{\prime} 40.8^{\prime \prime E}$; station 2: $29^{\circ} 20^{\prime} 40.0^{\prime \prime} \mathrm{N} 71^{\circ} 01^{\prime} 12.5 " \mathrm{E}$; station 3: $29^{\circ} 20^{\prime} 59.6^{\prime \prime} \mathrm{N} 71^{\circ} 01^{\prime} 21.2^{\prime \prime} \mathrm{E}$ ) (Fig. 1). The sites were selected to observe different levels of 
pollutant accumulation. Three replications were conducted during each season at each site for the current study. Nine replications were considered for each experimental factor.

\section{Sample collection and processing}

Water samples for heavy metals determination were collected from each study site in acidwashed polyethylene bottles. In the field, the bottles were rinsed several times with the river water and $100 \mathrm{ml}$ of water sample was then collected from $150 \mathrm{~cm}$ below the water surface. After that, the water samples were acidified with concentrated hydrochloric acid ( $\mathrm{HCl}, 37 \%$, Merck, Germany) for preservation. The solution was then transferred into a conical flask and heated at $105{ }^{\circ} \mathrm{C}$ on a hot plate to evaporate the solution to $25 \mathrm{ml}$. It was then transferred into a $100 \mathrm{ml}$ volumetric flask and distilled water was added to fill up to the mark where it was filtered with Whatman filter paper\# 44 and then transferred to a pre-cleaned sample bottle for Atomic Adsorption Spectrophotometer (AAS) analysis.

Sediment samples of the river were collected with the help of a PVC pipe $(5 \mathrm{~cm}$ diameter) pressed with pressure through the water column to obtain the sediment layer of about $0.25 \mathrm{~m}$. Polyethylene scoops and cans were used to collect samples from the PVC pipe. Each sample was consisted of $500 \pm 20 \mathrm{~g}$ of the surface layer from river bed sediments. The samples were kept below $10{ }^{\circ} \mathrm{C}$ by placing in ice bags during transportation to the laboratory and then stored in a deep freezer at $-20^{\circ} \mathrm{C}$ for further analysis. After air-drying for 3 days, the sediment samples were ground into smaller particles. Samples were sieved and run through the digestion process. For the digestion process, $2 \mathrm{~g}$ of air-dried sediment sample was weighed and poured into a $100 \mathrm{ml}$ beaker. Five-millilitre hydrogen trioxonitrate acid $\left(\mathrm{HNO}_{3}, 65 \%\right.$, Merck, Germany), $2 \mathrm{ml}$ perchloric acid $\left(\mathrm{HClO}_{4}, 70-72 \%\right.$, Merck, Germany) and $5 \mathrm{ml}$ hydrogen fluoride (HF, 48\%, Merck, Germany) was added to the sample according to the Hseu et al. (2002) and then heated for 1 hour at $160{ }^{\circ} \mathrm{C}$. After proper digestion, the sample was allowed to cool down and then filtered properly. The filtrate was transferred into a 100 
$\mathrm{ml}$ volumetric flask and made up to mark with distilled water. The prepared sample solution was transferred into the pre-cleaned labelled sample bottles in readiness for AAS analysis.

The plankton samples were collected by filtering nearly $100 \pm 10 \mathrm{~L}$ of water using the plankton net of $10 \mu \mathrm{m}$ pore capacity and $30 \mathrm{~cm}$ in diameter. Sampled plankton was acidified by using $\mathrm{HCl}$ and then transferred to the laboratory for analysis. Plankton samples were digested using $\mathrm{HNO}_{3}$ (65\%, Merck, Germany) and $\mathrm{HClO}_{4}(70 \%$ - 72\%, Merck, Germany) (1:3 v/v) and analysed for metals by using methods of APHA (2005). The planktonic abundance on the dry weight basis was determined by the evaporation method (Javed 1988) through the following formula:

$\boldsymbol{i}$ : Total solids $(\mathrm{TS})=$ weight of the beaker with an oven-dried sample of water - weight of the empty beaker

ii: Total dissolved solids (TDS) $=$ weight of the beaker with an oven-dried sample of filtered water - weight of the empty beaker

iii: Dry weight of Plankton Biomass (Abundance) $=$ TS - TDS

Both TS and TDS were calculated by the evaporation method. To calculate TS, a onelitre sample of river water was taken in a pre-weighed beaker and then placed in a laboratory oven (Model \#DHG-9053A, Shanghai Sunrise Instrument Co., Ltd.) at $103{ }^{\circ} \mathrm{C}$ for evaporation. The beaker with oven-dried samples was weighed again and the weight of the empty beaker was subtracted from it to determine TS. TDS were determined by filtering the river water through Whatman filter paper\# 44 and then dried weight (TDS) of the filtered water was calculated. Finally, the dry weight of plankton biomass was calculated simply by subtracting the TDS from TS.

\section{Determination of metals and arsenic}

Firstly, the standard solutions of studied metals were prepared to calibrate the instrument on the day of actual metal detection analysis to avoid possible deterioration of prepared 
standards. All samples were prepared with analytical grade chemicals and double-distilled water. Water was double distilled in automatic water still (Aquatron A4000D, Cole-Parmer Ltd, UK). Atomic Absorption Spectrophotometer was set-up with the flame condition and observance was optimized for the metal analysis. Water was double distilled and deionized in a water deionizer (Aquatron, AdhSingle, Cole-Parmer Ltd, UK) which was used as blank. Blanks, standards CRMs, sample blank and samples were aspirated into the flame in a Flame Atomic Absorption Spectrometer (Analyst 400, PerkinElmer, Inc. USA). The least-square design was implemented to statistically analyse the data using the fitting of a straight line. A blank reading was also taken to adjust the calibrations for the calculation of individual metal. Concentrations of As and other heavy metals including $\mathrm{Pb}, \mathrm{Al}$, and $\mathrm{Ba}$ were assayed using AAS with the standard analytical protocol (Table 1) according to method\# 3500-Al B, 3500As B, 3500-Ba B, 3500-Pb B of APHA (2005), respectively. Three replications of each metal were run through the AAS for each experiment (Water, sediments and plankton).

\section{Health risk assessment}

Three major pathways are generally considered in human health risk assessment: ingestion, dermal contact and respiration. This study focused on the ingestion and dermal contact pathways. The following equations (Equation 1 and 2) are applied in calculating the exposure through these two pathways (Ezemonye et al. 2019; Filipsson et al. 2009; Iqbal et al. 2013):

Equation 1: For sediment: Exp ing $=\frac{\mathrm{C} \times \mathrm{IR} \times \mathrm{CF} \times \mathrm{EF} \times \mathrm{ED}}{\mathrm{BW} \times \mathrm{AT}}$; For water: $\operatorname{Exp}_{\text {ing }}=\frac{\mathrm{C} \times \mathrm{IR} \times \mathrm{EF} \times \mathrm{ED}}{\mathrm{BW} \times \mathrm{AT}}$

Equation 2: For sediment: $\operatorname{Exp}_{\text {derm }}=\frac{\mathrm{C} \times \mathrm{CF} \times \mathrm{SA} \times \mathrm{AF} \times \mathrm{ABS} \times \mathrm{EF} \times \mathrm{ED}}{\mathrm{BW} \times \mathrm{AT}}$; For water: $\mathrm{Exp}_{\mathrm{derm}}=\frac{\mathrm{C} \times \mathrm{SA} \times \mathrm{KP} \times \mathrm{ET} \times \mathrm{EF} \times \mathrm{ED} \times \mathrm{CF}}{\mathrm{BW} \times \mathrm{AT}}$

Where Exping is the ingestion exposure from the sediment or water; $\mathrm{C}$ represents the measured concentration in the sediment or water; IR is the ingestion rate (114 mg/day); CF represents the unit conversion factor $\left(10^{-6} \mathrm{~kg} / \mathrm{mg}\right)$; EF is the exposure frequency (350 days/year); ED represents the exposure duration (30 years); BW is the body weight (70 $\mathrm{kg}$ ); 
199

200

201

202

203

204

205

206

207

208

209

210

211

212

213

214

215

216

217

218

219

220

221

222

AT represents the average day (10,950 days); Exp $_{\text {derm }}$ is the dermal uptake; SA is the exposed skin surface area $\left(5700 \mathrm{~cm}^{2}\right)$; AF represents the adherence factor from sediment to the skin $\left(0.07 \mathrm{mg} / \mathrm{cm}^{2}\right)$; ABS is the dermal absorption from sediment $(0.001 \mathrm{~cm} / \mathrm{h})$; ET is the exposure time (assumed to be $2 \mathrm{~h} /$ day); KP is the dermal permeability coefficient $(0.001 \mathrm{~cm} / \mathrm{h})$.

Hazardous quotients (HQs) are used to assess the noncarcinogenic health risks following exposure to heavy metals and arsenic in sediment according to the USEPA (2004) health risk assessment guidelines. The following equations are adopted to evaluate the HQs for the two exposure pathways (Equation 3 and 4):

Equation 3: $\quad$ For sediment: $\mathrm{HQ}_{\text {ing/derm }}=\frac{\text { Exp }_{\text {ing/derm }}}{R f D} ; \quad$ For water: $\mathrm{HQ}=\frac{E x p_{\text {ing }}}{R f D}$

Equation 4: $\quad \mathrm{HI}=\sum_{\mathrm{i}=1}^{\mathrm{n}} \mathrm{HQ}_{\text {ing } / \text { derm }}$

Where HQ is health HQs via ingestion or dermal contact under the respective exposure amount; RfD represents the reference dose for the resulting hazardous health effect caused by contaminants. The reference dose via dermal contact is typically hypothesized to be identical to the reference dose via ingestion for heavy metals in sediment (Iqbal et al. 2013). HI represents hazardous index.

\section{Carcinogenic risk (CR)}

The parameter was calculated based on equation 5 (Jiang et al. 2017):

Equation 5:

$$
C R=A D D \cdot C S F
$$

ADD - an average daily dose of a pollutant,

$\mathrm{CSF}$ - carcinogenic slope factor $\left(\mathrm{mg} \mathrm{kg}^{-1}\right.$ per day, 0.35 and 0.5 for $\mathrm{Cd}$ and $\mathrm{Cr}$, respectively); (ATSDR 2010; USEPA 2005). 
224 The parameter is calculated based on equation 6 (Cui et al., 2004).

225 Equation 6:

$$
T F=\frac{C_{\text {plankton }}}{C_{\text {water }}}
$$

$\mathrm{C}_{\text {plankton }}-$ metal concentration in plankton $\left(\mathrm{mg} \mathrm{kg}^{-1}\right), \mathrm{C}_{\text {water }}-$ metal concentration in water $(\mathrm{mg}$ $\left.\mathrm{L}^{-1}\right)$

\section{Statistical analysis}

Statistical analysis of data was carried out using the PASW Statistics Package (version 18).

Two-way Analysis of Variance (Two-way ANOVA) and Student Newman- Keul (SNK) tests were performed to find-out statistical differences of different heavy metals concerning sample seasons and sample stations. The significance level was set to $\alpha=0.05$ and values are given as mean \pm standard deviation.

\section{Results}

Contamination level of heavy metals $(\mathrm{Al}, \mathrm{As}, \mathrm{Ba}$, and $\mathrm{Pb})$ in the water of Punjnad Headworks were analysed and their mean $( \pm \mathrm{SD})$ were compared (Table 1$)$. The mean concentration of As and heavy metals in the water samples showed the descending order as $\mathrm{Pb}>\mathrm{Al}>\mathrm{Ba}>\mathrm{As}$. The highest and lowest concentration of Al during three seasons was observed in stations 1 and 3, respectively. The highest and lowest levels of Ba were reported in station 3 and 1, respectively. For arsenic and lead metals, the highest and lowest concentrations were observed at stations 3 and 2, respectively. Moreover, the highest and lowest mean level of all metals (except for lowest $\mathrm{Pb}$ levels) among the three stations was found in the spring and the autumn seasons, respectively. An overall significant difference $(p<0.05)$ of Al was recorded among three sampling stations. Similarly, the Al concentrations were found to be significantly different ( $p$ $<0.05$ ) among the three sampling seasons. Also, using two-way ANOVA statistical analysis the effect of stations and seasons in the accumulation of heavy metals in surface water was studied. Results indicated that all heavy metals concentrations differed significantly $(p<0.05)$ 
among stations and seasons. Moreover, the mean concentrations of $\mathrm{Al}$ and $\mathrm{Pb}$ in the water of Punjnad Headworks were much higher than the WHO and USEPA standards for the same metals (Table 1).

Heavy metals levels in the bed sediments were in the orders of $\mathrm{Al}>\mathrm{Pb}>\mathrm{As}>\mathrm{Ba}$

252

253

254

255

256

257

258

259

260

261

262

263

264

265

266

267

(Table 2). A comparison of the average concentrations of As and heavy metals in the different sites and samples revealed that the average Al concentration was higher $\left(519.19 \pm 1.808 \mu \mathrm{g} \mathrm{g}^{-1}\right)$ than that of other metals. Among three seasons, the highest concentrations of $\mathrm{Pb}, \mathrm{As}, \mathrm{Ba}$ and Al metals were observed at stations 2, 1, 1 and 3, respectively, while the lowest concentrations of these metals were reported at stations 1, 2, 3, and 1, respectively. The highest and lowest concentrations of heavy metals were observed in the autumn and were related to $\mathrm{Al}$ $\left(501.96 \pm 15.24 \mu \mathrm{g} \mathrm{g}^{-1}\right)$ and $\mathrm{Ba}\left(3.63 \pm 1.76 \mu \mathrm{g} \mathrm{g}^{-1}\right)$, respectively. The mean concentration of As and $\mathrm{Pb}$ determined in this study ranged from $30.95 \pm 7.81$ to $85.45 \pm 5.39 \mu \mathrm{g} \mathrm{g}^{-1}$. Findings of this study showed that two experimental factors, seasons and stations had an interactive effect on the accumulation of As and heavy metals in sediments i.e., a significant difference (two-way ANOVA; $p<0.00)$ in all metals was found among sampling stations, seasons and their interaction. The mean concentrations of $\mathrm{As}$ and $\mathrm{Pb}$ in the sediment of Punjnad Headworks were higher than the recommended limit documented by (MacDonald et al. 2000).

The concentration level $\left(\mu \mathrm{g} \mathrm{g}^{-1}\right)$ of different As and heavy metals in plankton were studied in different seasons and at different sampling stations (Table 3). The trend of accumulation of As and heavy metals in plankton were similar to the trend in sediments, so it was found that the metals levels were $\mathrm{Al}>\mathrm{Pb}>\mathrm{As}>\mathrm{Ba}$, respectively. Also, the highest and lowest concentrations of metals in the fall were attributed to $\mathrm{Al}\left(349.06 \pm 5.92 \mu \mathrm{g} \mathrm{g}^{-1}\right)$ and $\mathrm{Ba}$ $\left(1.64 \pm 0.35 \mu \mathrm{g} \mathrm{g}^{-1}\right)$, respectively. The highest concentrations of As and $\mathrm{Pb}$ were at station 1 , while the lowest concentrations of these pollutants were at stations 2 and 3, respectively. An overall significant difference $(p<0.05)$ in mean of all metals were found among three sampling 
stations. Similarly, the mean of all metals were significantly different $(p<0.05)$ among the three sampling seasons. Moreover, the statistical interaction between the sampling stations and sampling seasons for the mean concentration of all metals were also statistically different $(p<$ 0.05). The correlation of different metals in water, sediments and plankton was also analysed (Table 4). The result obtained showed a positive correlation among all the studied metals in water, while in sediments Al was negatively correlated to all other metals. Arsenic was negatively correlated to $\mathrm{Al}$ and $\mathrm{Ba}$. However, As did not show a significant relation with $\mathrm{Pb}$. Barium was negatively correlated to $\mathrm{Al}$ and $\mathrm{As}$, while positively correlated to $\mathrm{Pb}$. The $\mathrm{Pb}$ was found to be positively correlated to $\mathrm{Ba}$, negatively correlated to $\mathrm{Al}$ and non-significantly related to As. In samples collected from the plankton, a positive correlation was observed for all the metals except for the $\mathrm{Ba}$ and $\mathrm{Al}$.

\section{Health risk assessment}

Different health risk assessment parameters were applied to evaluate the hazardous effects of As and heavy metals on human health (Table 5). The obtained Exping and Expderm values showed that no significant adverse effects of studied heavy metals ( $\mathrm{Pb}, \mathrm{Al}, \mathrm{As}$ and $\mathrm{Ba}$ ) were observed with the quantity present in the water and sediment samples at the studied sites. However, the non-carcinogenic ( $\left.\mathrm{HQ}_{\text {ing/derm }}\right)$ and $\mathrm{HI}$ values showed adverse effects of $\mathrm{Pb}$ and As in the water, while a non-significant impact of Al was observed in water. Furthermore, the $\mathrm{HQ}_{\text {ing/derm }}$ for the sediments showed a non-significant impact of As and heavy metals on human health. Carcinogenic (CR) effects of $\mathrm{Pb}$ and As were found to be non-significant, while these values for $\mathrm{Al}$ and $\mathrm{Ba}$ could not be calculated due to lack of required data. Lastly, the Transfer Factor $(\mathrm{TF})$ values for the plankton $\left(T F_{\text {plankton}}\right)$ were found highest in As (33430.38) followed by $\mathrm{Al}$ (1436.94) and $\mathrm{Ba}$ (184.39), while the lowest value was observed in $\mathrm{Pb}(86.3)$. 
297 We found a significant amount of heavy metals and As at different sampling sites (station I, station II and station III) of the Punjnad headworks. A significant variations in the number of metals were present at different sampling sites. This study concluded that the river water at this location exhibited a significantly higher level of $\mathrm{Pb}$ followed by $\mathrm{Al}, \mathrm{Ba}$ and As. The quality of drinking water has been regarded as a major factor to influence human health. The concentrations of $\mathrm{Pb}, \mathrm{Al}$, As and $\mathrm{Ba}$ showed significant variations seasonally in a water bodies naturally or due to anthropogenic factors i.e., discharge of untreated contaminated water from various industries, agricultural practices, accelerated variations in physicochemical parameters of water, temperature, redox condition and river flow. Higher $\mathrm{Pb}$ toxicity level observed in this study could be due to agricultural runoff and heavy discharge of untreated industrial effluents in the riverine system, resulting in $\mathrm{pH}$ decline to elevate lead level in river water as previously determined by Y1lmaz and Sadikoglu (2011). Youssef et al. (2018) recorded higher Pb levels in the river water of Sohag governorate, Egypt. Similarly, our results are coherent with Khan et al. (2018) who found higher values of As compared to other metals in the water of Kabul river, Pakistan. The mean concentration of $\mathrm{Pb}$ in water was $9.85 \mathrm{mgL}^{-1}$ and $16.83 \mathrm{mgL}^{-1}$ during summer and winter, respectively, which were higher than the drinking water quality standard (Ali et al. 2016). The chemistry of toxicity and bioavailability of $\mathrm{Al}$ in the aquatic environment is complex and affected by a wide range of water quality parameters including $\mathrm{pH}$, water hardness and dissolved organic carbon (Camargo et al. 2009; Cardwell et al. 2018; Gensemer et al. 2018). The slow and steady dissolution and precipitation of $\mathrm{Al}$ was frequently observed in acidic waters (low pH) (Cardwell et al. 2018). Thus, acidic soil would be a major cause for the mobilization of $\mathrm{Al}$ to the aquatic ecosystems (Adams et al. 2018). In the current study, significantly higher concentrations of $\mathrm{Al}$ was detected in the riverine water which could be the 
result of lower $\mathrm{pH}$ of water. Aqueous $\mathrm{Al}$ is measured as the main toxic agent leading to fish mortality in the water with a lower pH (Cardwell et al. 2018).

In the freshwater, the toxicity of several heavy metals has been detected by analysing their effects in water, sediments and fish (Islam et al. 2017; Pal and Maiti 2018; Naz et al., 2020). Overall, the toxicity level of all analysed metals (Al, Ba, As and $\mathrm{Pb}$ ) recorded at Punjnad headworks were significantly lower in the water samples as compared to bed sediments and plankton. The heavy metals complex that is mobilized into the water bodies from different sources are actively absorbed by the planktons (Al-Imarah et al. 2018; Yi et al. 2017) and some quantities could be deposited on the suspended particles that sink down and ultimately become the part of sediments of a water body. Due to the physicochemical properties of water, an immobilized form of heavy metals present in sediments become mobilized again in aquatic habitat (Ekengele et al. 2017; Jindal and Sharma 2011; Pandey and Singh 2017). The toxicity level of all the metals ( $\mathrm{Al}, \mathrm{As}$ and $\mathrm{Pb}$ ) except $\mathrm{Ba}$ were significantly higher in all the study sites of Punjnad headworks. The metals deposited in sediments of the water body become a source of substantial hazards to detritus-feeding benthic organisms and ultimately led to a permanent source of potential toxicity to the higher tropic levels of a food chain/web (Ali and Khan 2018; Hanif et al. 2016). Islam et al. (2017) reported the mobilization of heavy metals in sediment deposits of Paira River, Bangladesh. The toxicity level of both $\mathrm{Ba}$ and As in the water and sediments, collected from Punjnad headworks at three sampling sites, were measured significantly lower than $\mathrm{Al}$ and $\mathrm{Pb}$. It has been reported that the toxic nature of As is due to its binding ability to the thiol groups of proteins ultimately inhibiting the enzymatic activities in a living body (Rezaei et al. 2017; Tian et al. 2018). The present study showed that accumulation of studied metals by the aquatic organism and sediments were highly dependent upon the metallic contamination of the water body. The ultimate sink of chemical effluents poured directly into the water bodies is the sediments and hence becomes a source of pollution (Das et 

plankton and sediments represent their role as bio-indicator of the metallic toxicity in the Punjnad headworks of Chenab river. The physical and biological processes have insistent potential to deduct metals from the aquatic body, accumulate and store them for a long duration even at low concentrations. Therefore, the sediment, suspended particulate matter and physicochemical characteristics of water have a significant effect on metal toxicity in an aquatic ecosystem (Boran and Altınok 2010; Das et al. 2017). metals, As-Al, $\mathrm{Ba}-\mathrm{Al}, \mathrm{Pb}-\mathrm{Al}, \mathrm{Pb}-\mathrm{As}, \mathrm{Pb}-\mathrm{Ba}$, and $\mathrm{Ba}-\mathrm{As}$ in water; and $\mathrm{Pb}-\mathrm{As}$ in plankton have a strong positive correlation, and $\mathrm{Ba}-\mathrm{Al}$ in sediment has a highly negative correlation. We hypothesize that heavy metals with a high positive correlation are possibly from the similar primary pollutant sources, i.e., industrial discharge, while the metal with a highly negative correlation are possibly from the different pollutant sources. These heavy metals are widely used as raw materials or process catalysts to produce alloys, steels and various other industrial purposes. Many previous studies have reported significant quantities of industrial wastes/wastewater being discharged into the Punjnad headworks (Hanif et al. 2016; Fatima et al. 2020). In addition, deposition of heavy metals through industrial emissions can also be considered as a source of metal contamination in the study area. It is found that the industrial wastes from different cities in Punjab are being dumped into the major rivers of Punjab province which ultimately sink into the Punjnad Headworks (Hanif et al. 2016). A positive correlation among trace metals and dissolved organic carbon concentration ratios was observed in freshwater ecosystem (Kikuchi et al. 2017). Similarly, Ni et al. (2016), found a significant correlation between heavy metals concentration and freshwater microbial ecology. A significant positive correlation among some metals, while negative pattern among other metals were observed in the food web in the upper Yangtze River, China (Yi et al. 2017). 

human health risk assessment and $\mathrm{HQ}$ (ing/derm) values for $\mathrm{As}$ and $\mathrm{Pb}$ in water were higher than 1, indicating obvious health risk from these pollutants in water over a lifetime of exposure. While, the hazard index $(\mathrm{HI})$ values for water was less than 1, indicating no adverse health risk for non-carcinogenic effect. The HQ values of the sediment and dermal contact with the sediment of noncarcinogenic As and heavy metals in the river sediment are less than 1 , indicating that the selected metals and As would not pose any adverse non-carcinogenic health risks to the inhabitants during the seasons. The noncarcinogenic health risk through ingestion was higher than that of dermal contact, indicating that the ingestion pathway significantly contributed to the health risk of the contaminated sediments. Moreover, the noncarcinogenic HI of heavy-metal-contaminated sediment was less than 1 . The TF values from water to plankton were found highest and lowest in $\mathrm{As}$ and $\mathrm{Pb}$, respectively. These values were greater than 1 , suggesting that the plankton will have a greater chance of the metal uptake by anthropogenic activities, which can be used for phytoremediation (Mirecki et al. 2015). The cancer risk (CR) was determined based on the intake level of inorganic $\mathrm{As}$ and $\mathrm{Pb}$, which may increase carcinogenic effects depending on the exposure dose (Aligol et al. 2017; EPA 2016). Briefly, based on our findings, the chance of developing CR contact for both elements in water was $1.85 \times 10^{-3}$ and $6.02 \times 10^{-3}$, respectively. Thus, the CR values were above the safety level $\left(1 \times 10^{-4}\right)$ recommended by the US EPA (Alidadi et al. 2019), suggesting the probability of carcinogenic risk for the human consumption of drinking water. While, the mean CR values for $\mathrm{As}$ and $\mathrm{Pb}$ in sediment was $7.30 \times 10^{-5}$ and $6.02 \times 10^{-7}$, respectively, suggesting carcinogenic risk can be acceptable for human via ingestion and dermal contact. Similarly, (Sayadi et al. 2020) and (Hu et al. 2017) reported CR values between $10^{-4}$ and $10^{-6}$. 


\section{Conclusion:}

394 This study concluded important information on the heavy metals content at Punjnad 395 headworks. According to this study $\mathrm{Al}, \mathrm{As}, \mathrm{Ba}$ and $\mathrm{Pb}$ contents were present in different 396 concentrations at all three sites from where the samples were collected. Heavy metals and As 397 contents were highest in spring, while lowest in winter. Presence of heavy metals and As in 398 significant concentration in these waters is a serious health issue. Proper preventive measures including regulation of the industrial, agricultural and domestic discharge of waste materials

400

401

402

403

404

405

406

407

408

409

410 must be carried out to reduce contamination and pollution in the rivers. Further in-depth studies are required to explore the burden of potentially hazardous heavy metals in river waters which poses serious health risk for human, animals and aquatic organism.

\section{Acknowledgement}

We are thankful to the Higher Education Commission of Pakistan (HEC) for funding this research project (Grant number: 21-1041/SRGP/R\&D/HEC/2016). We are also grateful to the Deputy Director of Fisheries, Punjab, Bahawalpur division and its team for their assistance in collections of samples from Punjnad Headworks.

\section{Funding}

Higher Education Commission of Pakistan (HEC) funded this research project under Start-up Research Grant Program (SRGP) with Grant number: 21-1041/SRGP/R\&D/HEC/2016. 
412 SN and BM designed the study; AMMC collected the sample, QU, ZUA and MZK wrote and 413 submitted the manuscript, AK, SS and RAB edited and reviewed the manuscript.

414 Declarations

Ethics approval and consent to participate

416

Not applicable.

417

Consent for publication

418

Not applicable

419

Availability of data and material

420

Do not wish to share.

421

Competing interests

422

The authors declare that they have no competing interests. 
Adams WJ, Cardwell AS, DeForest DK, Gensemer RW, Santore RC, Wang N, Nordheim E (2018) Aluminum bioavailability and toxicity to aquatic organisms: Introduction to the special section. Environ Toxicol Chem 37:34-35. https://doi.org/10.1002/etc.3879

Al-Imarah FJ, Khalaf TA, Ajeel SG, Khudhair AY, Saad R (2018) Accumulation of heavy metals in zooplanktons from Iraqi national waters. Int $\mathbf{J}$ Mar Sci 8:25-34. https://doi.org/10.5376/ijms.2018.08.0003

Ali H, Khan E (2018) Assessment of potentially toxic heavy metals and health risk in water, sediments, and different fish species of River Kabul, Pakistan. Hum Ecol Risk Assess: Int J 24:2101-2118. https://doi.org/10.1080/10807039.2018.1438175

Ali MM, Ali ML, Islam MS, Rahman MZ (2016) Preliminary assessment of heavy metals in water and sediment of Karnaphuli River, Bangladesh. Environ Nanotechnol Monit Manag 5:27-35. https://doi.org/10.1016/j.enmm.2016.01.002

Ali Z, Malik RN, Qadir A (2013) Heavy metals distribution and risk assessment in soils affected by tannery effluents. Chem Ecol 29:676-692. https://doi.org/10.1080/02757540.2013.810728

Alidadi H, Tavakoly Sany SB, Zarif Garaati Oftadeh B, Mohamad T, Shamszade H, Fakhari M (2019) Health risk assessments of arsenic and toxic heavy metal exposure in drinking water in northeast Iran. Environ Health Prev Med 24:59. https://doi.org/10.1186/s12199-019-0812-x

Aligol M, Mohammadi NK, Mohamadbeigi A, Hardy LL, Ramezankhani A (2017) Physical activity and associated factors among women in a suburban area: findings of a community-based study in Iran. J Fundam Appl Sci 9:1313-1326. https://doi.org/10.4314/jfas.v9i1s.785

APHA (2005) Standard methods for the examination of water and wastewater. 
ATSDR (2010) Toxicological profile information sheet. Agency for Toxic Substances and Disease Registry, Public Health Service, U.S. Department of Health and Human Services.

ATSDR (2019) Substance Priority List. Division of Toxicology and Human Health Sciences, Atlanta, GA. https://www.atsdr.cdc.gov/spl/index.html\#2019spl

Bhatti SG, Tabinda AB, Yasin F, Mehmood A, Salman M, Yasar A, Rasheed R, Wajahat R (2019) Ecological risk assessment of metals in sediments and selective plants of Uchalli Wetland Complex (UWC)-a Ramsar site. Environ Sci Pollut Res 26:19136-19152. https://doi.org/10.1007/s11356-019-04711-3

Boran M, Altınok I (2010) A review of heavy metals in water, sediment and living organisms in the Black Sea. Turkish J Fish Aquat Sci 10:565-572. https://doi.org/10.1002/047147844x.wq428

Camargo MM, Fernandes MN, Martinez CB (2009) How aluminium exposure promotes osmoregulatory disturbances in the neotropical freshwater fish Prochilus lineatus. Aquat Toxicol 94:40-46. https://doi.org/10.1016/j.aquatox.2009.05.017

Cardwell AS, Adams WJ, Gensemer RW, Nordheim E, Santore RC, Ryan AC, Stubblefield WA (2018) Chronic toxicity of aluminum, at a $\mathrm{pH}$ of 6 , to freshwater organisms: Empirical data for the development of international regulatory standards/criteria. Environ Toxicol Chem 37:36-48. https://doi.org/10.1002/etc.3901

Das S, Hossain K, Mustafa M, Parvin A, Saha B (2017) Physicochemical Properties of Water and Heavy Metals Concentration of Sediments, Feeds and Various Farmed Tilapia (Oreochoromis niloticus) In Bangladesh. Fish Aquac J 8:232. https://doi.org/10.4172/2150-3508.1000232 
Dutton CL, Subalusky AL, Anisfeld SC, Njoroge L, Rosi EJ, Post DM (2018) The influence of a semi-arid sub-catchment on suspended sediments in the Mara River, Kenya. PloS One 13:e0192828. https://doi.org/10.1371/journal.pone.0192828

Ekengele LN, Blaise A, Jung MC (2017) Accumulation of heavy metals in surface sediments of Lere Lake, Chad. Geosci J 21:305-315. https://doi.org/10.1007/s12303-016-0047-4 EPA (2016) Integrated risk information system. Washington

Eqani SA-M-A-S, Malik RN, Mohammad A (2011) The level and distribution of selected organochlorine pesticides in sediments from River Chenab, Pakistan. Environ Geochem Health 33:33-47. https://doi.org/10.1007/s10653-010-9312-Z

Ezemonye LI, Adebayo PO, Enuneku AA, Tongo I, Ogbomida E (2019) Potential health risk consequences of heavy metal concentrations in surface water, shrimp (Macrobrachium macrobrachion) and fish (Brycinus longipinnis) from Benin River, Nigeria. Toxicol Rep 6:1-9. https://doi.org/10.1016/j.toxrep.2018.11.010

Fatima S, Iqbal KJ, Atique U, Javid A, Khan N, Iqbal S, Majeed H, Azmat H, Khan BYA, Irfan I, Shahid MT, Afzal G (2020) Toxic trace metals assessment in selected organs of edible fish species, sediment and water in Head Punjnad, Punjab, Pakistan. Punjab Univ J Zool 35:43-50. https://doi.org/10.17582/journal.pujz/2020.35.1.43.50

Ferreira MdS, Fontes MPF, Pacheco AA, Lima HN, Santos JZL (2020) Risk assessment of trace elements pollution of Manaus urban rivers. Sci Total Environ 709:134471. https://doi.org/10.1016/j.scitotenv.2019.134471

Filipsson M, Lindström M, Peltola P, Öberg T (2009) Exposure to contaminated sediments during recreational activities at a public bathing place. J Hazard Mater 171:200-207. https://doi.org/10.1016/j.jhazmat.2009.05.128

Gensemer RW, Gondek JC, Rodriquez PH, Arbildua JJ, Stubblefield WA, Cardwell AS, Santore RC, Ryan AC, Adams WJ, Nordheim E (2018) Evaluating the effects of pH, 
hardness, and dissolved organic carbon on the toxicity of aluminum to freshwater aquatic organisms under circumneutral conditions. Environ Toxicol Chem 37:49-60. https://doi.org/10.1002/etc.3920

Hanif N, Eqani SAMAS, Ali SM, Cincinelli A, Ali N, Katsoyiannis IA, Tanveer ZI, Bokhari H (2016) Geo-accumulation and enrichment of trace metals in sediments and their associated risks in the Chenab River, Pakistan. J Geochem Explor 165:62-70. https://doi.org/10.1016/j.gexplo.2016.02.006

Heise S, Förstner U (2007) Risk assessment of contaminated sediments in river basinstheoretical considerations and pragmatic approach. J Environ Monit 9:943-952. https://doi.org/10.1039/b704071g

Howes M, Wortley L, Potts R, Dedekorkut-Howes A, Serrao-Neumann S, Davidson J, Smith T, Nunn P (2017) Environmental sustainability: a case of policy implementation failure? Sustainability 9:165. https://doi.org/10.3390/su9020165

Hseu Z-Y, Chen Z-S, Tsai C-C, Tsui C-C, Cheng S-F, Liu C-L, Lin H-T (2002) Digestion methods for total heavy metals in sediments and soils. Water Air Soil Pollut 141:189205. https://doi.org/10.1023/A:1021302405128

Hu B, Jia X, Hu J, Xu D, Xia F, Li Y (2017) Assessment of heavy metal pollution and health risks in the soil-plant-human system in the Yangtze river delta, China. Int J Environ Res Public Health 14:1042. https://doi.org/10.3390/ijerph14091042

Huat TJ, Camats-Perna J, Newcombe EA, Valmas N, Kitazawa M, Medeiros R (2019) Metal toxicity links to alzheimer's disease and neuroinflammation. J Mol Biol 431:1843-1868. https://doi.org/10.1016/j.jmb.2019.01.018

Iqbal J, Tirmizi SA, Shah MH (2013) Statistical apportionment and risk assessment of selected metals in sediments from Rawal Lake (Pakistan). Environ Monit Assess 185:729-743. https://doi.org/10.1007/s10661-012-2588-y 
Islam M, Mostafa M (2018) Textile dyeing effluents and environment concerns-A review. J Environ Sci Nat Resour 11:131-144. https://doi.org/10.3329/jesnr.v11i1-2.43380

Islam MS, Ahmed MK, Habibullah-Al-Mamun M (2017) Heavy metals in sediment and their accumulation in commonly consumed fish species in Bangladesh. Arch Environ Occup Health 72:26-38. https://doi.org/10.1080/19338244.2016.1152946

Islam MS, Ahmed MK, Raknuzzaman M, Habibullah-Al-Mamun M, Masunaga S (2015) Metal speciation in sediment and their bioaccumulation in fish species of three urban rivers in Bangladesh. Arch Environ Contam Toxicol 68:92-106. https://doi.org/10.1007/s00244-014-0079-6

Javed M (1988) Growth performance and meat quality of major carps as influenced by pond fertilization and feed supplementatlon. University of Agriculture Faisalabad Pakistan

Javed M (2006) Studies on metal contamination levels in plankton and their role as biological indicator of water pollution in the river Ravi. Pak J Biol Sci 9:313-317. https://doi.org/10.3923/pjbs.2006.313.317

Jiang Y, Chao S, Liu J, Yang Y, Chen Y, Zhang A, Cao H (2017) Source apportionment and health risk assessment of heavy metals in soil for a township in Jiangsu Province, China. Chemosphere 168:1658-1668. https://doi.org/10.1016/j.chemosphere.2016.11.088

Jindal R, Sharma C (2011) Studies on water quality of Sutlej River around Ludhiana with reference to physicochemical parameters. Environ Monit Assess 174:417-425. https://doi.org/10.1007/s10661-010-1466-8

Khan KM, Chakraborty R, Bundschuh J, Bhattacharya P, Parvez F (2020) Health effects of arsenic exposure in Latin America: An overview of the past eight years of research. Sci Total Environ 710:136071. https://doi.org/10.1016/j.scitotenv.2019.136071

Khan MI, Khisroon M, Khan A, Gulfam N, Siraj M, Zaidi F, Ahmadullah, Abidullah, Fatima SH, Noreen S, Hamidullah, Shah ZA, Qadir F (2018) Bioaccumulation of heavy metals 
in water, sediments, and tissues and their histopathological effects on Anodonta cygnea (linea, 1876) in Kabul river, Khyber Pakhtunkhwa, Pakistan. Biomed Res Int 2018:1910274. https://doi.org/10.1155/2018/1910274

Kikuchi T, Fujii M, Terao K, Jiwei R, Lee YP, Yoshimura C (2017) Correlations between aromaticity of dissolved organic matter and trace metal concentrations in natural and effluent waters: A case study in the Sagami River Basin, Japan. Sci Total Environ 576:36-45. https://doi.org/10.1016/j.scitotenv.2016.10.068

Kravchenko J, Darrah TH, Miller RK, Lyerly HK, Vengosh A (2014) A review of the health impacts of barium from natural and anthropogenic exposure. Environ Geochem Health 36:797-814. https://doi.org/10.1007/s10653-014-9622-7

Li R, Tang X, Guo W, Lin L, Zhao L, Hu Y, Liu M (2020) Spatiotemporal distribution dynamics of heavy metals in water, sediment, and zoobenthos in mainstream sections of the middle and lower Changjiang River. Sci Total Environ 714:136779. https://doi.org/10.1016/j.scitotenv.2020.136779

MacDonald DD, Ingersoll CG, Berger T (2000) Development and evaluation of consensusbased sediment quality guidelines for freshwater ecosystems. Arch Environ Contam Toxicol 39:20-31. https://doi.org/10.1007/s002440010075

Mahfooz Y, Yasar A, Sohail MT, Tabinda AB, Rasheed R, Irshad S, Yousaf B (2019) Investigating the drinking and surface water quality and associated health risks in a semi-arid multi-industrial metropolis (Faisalabad), Pakistan. Environ Sci Pollut Res 26:20853-20865. https://doi.org/10.1007/s11356-019-05367-9

Mirecki N, Agic R, Sunic L, Milenkovic L, Ilic ZS (2015) Transfer factor as indicator of heavy metals content in plants. Fresenius Environ Bull 24:4212-4219. 
Mitra A, Chatterjee S, Gupta DK (2020) Environmental arsenic exposure and human health risk. In: Arsenic Water Resources Contamination. Springer, pp 103-129. $\underline{\text { doi: } 10.1007 / 978-3-030-21258-2}$

Naz, S., R. Hussain., Q. Ullah, A.M.M. Chatha, A. Shaheen and R.U. Khan (2020). Toxic effect of some heavy metals on hematology and histopathology of major carp (Catla catla). Environ Sci Pollut Res. https://doi.org/10.1007/s11356-020-10980-0

Ni C, Horton DJ, Rui J, Henson MW, Jiang Y, Huang X, Learman DR (2016) High concentrations of bioavailable heavy metals impact freshwater sediment microbial communities. Ann Microbiol 66:1003-1012. https://doi.org/10.1007/s13213-015-1189$\underline{8}$

Omwene PI, Öncel MS, Çelen M, Kobya M (2018) Heavy metal pollution and spatial distribution in surface sediments of Mustafakemalpaşa stream located in the world's largest borate basin (Turkey). Chemosphere 208:782-792. https://doi.org/10.1016/j.chemosphere.2018.06.031

Pal D, Maiti SK (2018) Seasonal variation of heavy metals in water, sediment, and highly consumed cultured fish (Labeo rohita and Labeo bata) and potential health risk assessment in aquaculture pond of the coal city, Dhanbad (India). Environ Sci Pollut Res 25:12464-12480. https://doi.org/10.1007/s11356-018-1424-5

Pandey J, Singh R (2017) Heavy metals in sediments of Ganga River: up-and downstream urban influences. Appl Water Sci 7:1669-1678. https://doi.org/10.1007/s13201-015$\underline{0334-7}$

Qadri R, Faiq MA (2020) Freshwater Pollution: Effects on Aquatic Life and Human Health. In: Qadri H, Bhat RA, Mehmood MA, Dar GH (eds) Fresh Water Pollution Dynamics and Remediation. Springer Singapore, Singapore, pp 15-26. doi:10.1007/978-981-13$\underline{8277-2 \_2}$ 
Rezaei M, Khodayar MJ, Seydi E, Soheila A, Parsi IK (2017) Acute, but not chronic, exposure to arsenic provokes glucose intolerance in rats: possible roles for oxidative stress and the adrenergic pathway. Can J Diabetes 41:273-280. https://doi.org/10.1016/j.jcjd.2016.10.008

Rezai H, Yusoff FM (2011) Heavy metals in Neuston from the straits of Malacca. J Per Gulf Mar Sci, 2:1-10.

Robin RS, Pradipta RM, Vardhan KV, Ganguly D, Abhilash KR, Balasubramanian T (2012) Heavy metal contamination and risk assessment in the marine environment of Arabian Sea, along the southwest coast of India. Am J Chem 2:191-208. https://doi.org/10.5923/j.chemistry.20120204.03

Sayadi MH, Kharkan J, Binkowski LJ, Moshgani M, Błaszczyk M, Mansouri B (2020) Cadmium and chromium levels in water and edible herbs in a risk assessment study of rural residents living in Eastern Iran. Environ Sci Pollut Res 27:9901-9909. https://doi.org/10.1007/s11356-020-07600-2

Schleiss AJ, Franca MJ, Juez C, De Cesare G (2016) Reservoir sedimentation. J Hydraul Res 54:595-614. https://doi.org/10.1080/00221686.2016.1225320

Tian H, Zhao Y, Megharaj M, He W (2018) Arsenate inhibition on kinetic characteristics of alkaline phosphatase as influenced by pH. Ecol Indic 85:1101-1106. https://doi.org/10.1016/j.ecolind.2017.11.041

USEPA (2005) Supplemental guidance for assessing cancer susceptibility from early-life exposure to carcinogens. Risk Assessment Forum, Washington, DC. http://www.epa.gov/ncea/raf

Ustaoğlu F, Islam MS (2020) Potential toxic elements in sediment of some rivers at Giresun, Northeast Turkey: A preliminary assessment for ecotoxicological status and health risk. Ecol Indic 113:106237. https://doi.org/10.1016/j.ecolind.2020.106237 
619 Wani AL, Ara A, Usmani JA (2015) Lead toxicity: a review. Interdiscip Toxicol 8:55-64. https://doi.org/10.1515/intox-2015-0009

621 Yi Y, Tang C, Yi T, Yang Z, Zhang S (2017) Health risk assessment of heavy metals in fish

622

623

624

625

626

627

628

629

630

631

632

633

634

635

636

637 and accumulation patterns in food web in the upper Yangtze River, China. Ecotoxicol Environ Saf 145:295-302. https://doi.org/10.1016/j.ecoenv.2017.07.022

Y1lmaz S, Sadikoglu M (2011) Study of heavy metal pollution in seawater of Kepez harbor of Canakkale (Turkey). Environ Monit Assess 173:899-904. https://doi.org/10.1007/s10661-010-1432-5

Youssef M, Morsy EM, Soliman SM, Abdel-Latief A-RE-S (2018) Heavy metal pollutants in fresh water. J Biomater Nanobiotechnol 2:46-50. https://doi.org/10.11648/j.jb.20180202.14

Yuan Z, Liu D, Masqué P, Zhao M, Song X, Keesing JK (2020) Phytoplankton Responses to Climate-Induced Warming and Interdecadal Oscillation in North-Western Australia. Paleoceanogr

Paleoclimatol 35:e2019PA003712. https://doi.org/10.1029/2019pa003712

Zeng J, Han G, Yang K (2020) Assessment and sources of heavy metals in suspended particulate matter in a tropical catchment, northeast Thailand. J Clean Prod 265:121898. https://doi.org/10.1016/j.jclepro.2020.121898 
Table 1: Heavy metal concentrations (Mean $\pm \mathrm{SD} ; \mu \mathrm{g} \mathrm{L}^{-1}$ ) at three sampling stations (I, II \& III) in the water of Punjnad Headworks

\begin{tabular}{|c|c|c|c|c|c|c|c|c|c|c|c|}
\hline \multirow[b]{2}{*}{$\begin{array}{l}\text { Heavy } \\
\text { Metals }\end{array}$} & \multirow[b]{2}{*}{ Season } & \multicolumn{4}{|c|}{ Sampling Stations } & \multicolumn{2}{|c|}{$\begin{array}{c}\text { Guideline value } \\
\text { (WHO, 2017; Zhou et } \\
\text { al. 2020)* } \\
\end{array}$} & \multicolumn{4}{|c|}{ ANOVA } \\
\hline & & $\mathrm{I}$ & II & III & Overall Means & WHO & USEPA & $\begin{array}{c}\text { Source of } \\
\text { variance }\end{array}$ & $d f$ & $F$-value & $\begin{array}{c}P- \\
\text { value }\end{array}$ \\
\hline \multirow[t]{4}{*}{ Aluminum } & Autumn & $155.60 \pm 1.07^{\text {a†口 }}$ & $116.32 \pm 1.16^{\mathrm{cz}}$ & $128.91 \pm 1.22^{\mathrm{bz}}$ & $133.61 \pm 16.71$ & & & Stations & 2 & 105846.43 & $<0.00$ \\
\hline & Winter & $204.09 \pm 0.84^{\mathrm{ay}}$ & $200.34 \pm 1.02^{\text {by }}$ & $195.77 \pm 0.66^{\mathrm{cy}}$ & $200.07 \pm 3.57$ & & & Seasons & 2 & 1085.88 & $<0.00$ \\
\hline & Spring & $331.99 \pm 3.77^{\mathrm{ax}}$ & $323.32 \pm 0.78^{\mathrm{bx}}$ & $316.99 \pm 0.97^{\mathrm{cx}}$ & $324.09 \pm 6.65$ & & & $\begin{array}{l}\text { Stations } \mathrm{x} \\
\text { Seasons }\end{array}$ & 4 & 356.09 & $<0.00$ \\
\hline & $\begin{array}{l}\text { Overall } \\
\text { Means }\end{array}$ & $230.56 \pm 75.85$ & $213.33 \pm 86.62$ & $213.88 \pm 79.33$ & $219.25 \pm 80.11$ & 200 & 200 & & & & \\
\hline \multirow[t]{4}{*}{ Arsenic } & Autumn & $0.25 \pm 0.02^{\mathrm{bz}}$ & $0.18 \pm 0.016^{\mathrm{cz}}$ & $0.31 \pm 0.02^{\mathrm{az}}$ & $0.25 \pm 0.06$ & & & Stations & 2 & 4369.99 & $<0.00$ \\
\hline & Winter & $0.47 \pm 0.013^{\text {by }}$ & $0.31 \pm 0.018^{\text {cy }}$ & $0.64 \pm 0.016^{\text {ay }}$ & $0.48 \pm 0.14$ & & & Seasons & 2 & 49402.05 & $<0.00$ \\
\hline & Spring & $1.56 \pm 0.021^{\mathrm{bx}}$ & $1.26 \pm 0.014^{\mathrm{cx}}$ & $2.13 \pm 0.019^{\mathrm{ax}}$ & $1.66 \pm 0.38$ & & & $\begin{array}{l}\text { Stations } \mathrm{x} \\
\text { Seasons }\end{array}$ & 4 & 1127.39 & $<0.00$ \\
\hline & $\begin{array}{l}\text { Overall } \\
\text { Means }\end{array}$ & $0.77 \pm 0.59$ & $0.58 \pm 0.49$ & $1.03 \pm 0.81$ & $0.79 \pm 0.66$ & 10 & 10 & & & & \\
\hline \multirow[t]{4}{*}{ Barium } & Autumn & $12.25 \pm 0.024^{\mathrm{cz}}$ & $13.38 \pm 0.023^{\mathrm{bz}}$ & $14.89 \pm 0.017^{\mathrm{az}}$ & $13.51 \pm 1.09$ & & & Stations & 2 & 84283.05 & $<0.00$ \\
\hline & Winter & $13.23 \pm 0.03^{\text {cy }}$ & $17.39 \pm 0.019^{\text {ay }}$ & $16.07 \pm 0.035^{\text {by }}$ & $15.57 \pm 1.76$ & & & Seasons & 2 & 314568.82 & $<0.00$ \\
\hline & Spring & $17.73 \pm 0.022^{\mathrm{cx}}$ & $18.09 \pm 0.019^{\mathrm{bx}}$ & $19.91 \pm 0.019^{\mathrm{ax}}$ & $18.58 \pm 0.97$ & & & $\begin{array}{l}\text { Stations x } \\
\text { Seasons }\end{array}$ & 4 & 19204.38 & $<0.00$ \\
\hline & $\begin{array}{l}\text { Overall } \\
\text { Means }\end{array}$ & $14.41 \pm 2.43$ & $16.29 \pm 2.12$ & $16.95 \pm 2.18$ & $15.89 \pm 2.47$ & 700 & 2000 & & & & \\
\hline \multirow[t]{4}{*}{ Lead } & Autumn & $347.52 \pm 0.273^{\text {cy }}$ & $385.61 \pm 0.234^{\mathrm{bz}}$ & $525.57 \pm 0.31^{\text {ay }}$ & $428.56 \pm 70.05$ & & & Stations & 2 & 382048.01 & $<0.00$ \\
\hline & Winter & $340.51 \pm 0.273^{\mathrm{bz}}$ & $424.45 \pm 0.233^{\text {ay }}$ & $338.68 \pm 0.26^{\mathrm{cz}}$ & $367.87 \pm 40.76$ & & & Seasons & 2 & 3481481.79 & $<0.00$ \\
\hline & Spring & $559.72 \pm 0.24^{\mathrm{bx}}$ & $528.49 \pm 0.32^{\mathrm{cx}}$ & $607.35 \pm 0.35^{\text {ax }}$ & $565.18 \pm 33.04$ & & & $\begin{array}{l}\text { Stations } \mathrm{x} \\
\text { Seasons }\end{array}$ & 4 & 437670.93 & $<0.00$ \\
\hline & $\begin{array}{l}\text { Overall } \\
\text { Means }\end{array}$ & $424.92 \pm 98.16$ & $446.17 \pm 61.46$ & $490.53 \pm 114.58$ & $453.87 \pm 96.86$ & 10 & 15 & & & & \\
\hline
\end{tabular}

*WHO: Guidelines for drinking water quality (WHO, 2017); Zhou et al. 2020

${ }^{\dagger}$ The different letters ( $a, b$, and c) in the same row, show significant difference among stations (I, II, and III) for the same heavy metal and season ( $p<0.05$ )

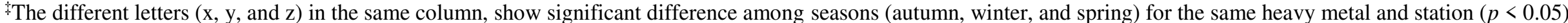


Table 2: Heavy metal concentrations (Mean $\pm \mathrm{SD} ; \mu \mathrm{g} \mathrm{g}^{-1}$ ) at three sampling stations (I, II \& III) in the sediments of Punjnad Headworks

\begin{tabular}{|c|c|c|c|c|c|c|c|c|c|c|c|c|}
\hline \multirow[b]{2}{*}{$\begin{array}{l}\text { Heavy } \\
\text { Metals }\end{array}$} & \multirow[b]{2}{*}{ Season } & \multicolumn{4}{|c|}{ Sampling Stations } & \multicolumn{3}{|c|}{ Background levels* } & \multicolumn{4}{|c|}{ ANOVA } \\
\hline & & $\mathrm{I}$ & II & III & Overall Means & TEL & LEL & MET & $\begin{array}{c}\text { Source of } \\
\text { variance }\end{array}$ & $d f$ & $F$-value & $P$-value \\
\hline \multirow[t]{4}{*}{ Aluminum } & Autumn & $428.91 \pm 1.62^{\mathrm{c \dagger x \neq}}$ & $503.78 \pm 1.74^{\mathrm{bx}}$ & $519.19 \pm 1.81^{\text {ax }}$ & $501.96 \pm 15.24$ & & & & Stations & 2 & 1838.27 & $<0.00$ \\
\hline & Winter & $352.15 \pm 1.23^{\mathrm{cy}}$ & $362.73 \pm 2.14^{\text {by }}$ & $378.75 \pm 1.83^{\text {ay }}$ & $364.55 \pm 11.27$ & & & & Seasons & 2 & 147621.56 & $<0.00$ \\
\hline & Spring & $233.39 \pm 1.62^{\mathrm{cz}}$ & $242.47 \pm 1.69^{\mathrm{bz}}$ & $256.79 \pm 1.86^{\mathrm{az}}$ & $244.22 \pm 9.96$ & & & & $\begin{array}{c}\text { Stations x } \\
\text { Seasons }\end{array}$ & 4 & 42.88 & $<0.00$ \\
\hline & $\begin{array}{l}\text { Overall } \\
\text { Means }\end{array}$ & $356.15 \pm 103.85$ & $369.65 \pm 108.84$ & $384.92 \pm 109.27$ & $370.24 \pm 106.60$ & - & - & - & & & & \\
\hline \multirow[t]{4}{*}{ Arsenic } & Autumn & $40.15 \pm 0.02^{\text {ay }}$ & $21.39 \pm 0.03^{\text {cy }}$ & $31.31 \pm 0.02^{\text {by }}$ & $30.95 \pm 7.81$ & & & & Stations & 2 & 4494756.19 & $<0.00$ \\
\hline & Winter & $39.27 \pm 0.02^{\mathrm{az}}$ & $19.26 \pm 0.02^{\mathrm{cz}}$ & $29.56 \pm 0.01^{\mathrm{bz}}$ & $29.37 \pm 8.33$ & & & & Seasons & 2 & 179664.65 & $<0.00$ \\
\hline & Spring & $42.36 \pm 0.03^{\mathrm{ax}}$ & $23.47 \pm 0.02^{\mathrm{cx}}$ & $33.74 \pm 0.02^{\mathrm{bx}}$ & $33.19 \pm 1.75$ & & & & $\begin{array}{c}\text { Stations x } \\
\text { Seasons }\end{array}$ & 4 & 2275.96 & $<0.00$ \\
\hline & $\begin{array}{l}\text { Overall } \\
\text { Means }\end{array}$ & $40.60 \pm 1.33$ & $21.37 \pm 1.75$ & $31.53 \pm 1.74$ & $31.17 \pm 8.06$ & 5.9 & 6 & 7 & & & & \\
\hline \multirow[t]{4}{*}{ Barium } & Autumn & $3.93 \pm 0.03^{\mathrm{bz}}$ & $5.56 \pm 0.03^{\mathrm{az}}$ & $1.37 \pm 0.02^{\mathrm{cz}}$ & $3.63 \pm 1.76$ & & & & Stations & 2 & 89875.99 & $<0.00$ \\
\hline & Winter & $4.33 \pm 0.05^{\text {by }}$ & $7.28 \pm 0.04^{\text {ay }}$ & $3.46 \pm 0.03^{\text {cy }}$ & $5.03 \pm 1.66$ & & & & Seasons & 2 & 50863.69 & $<0.00$ \\
\hline & Spring & $5.86 \pm 0.03^{\text {bx }}$ & $8.45 \pm 0.03^{\text {ax }}$ & $5.15 \pm 0.03^{c x}$ & $6.49 \pm 1.44$ & & & & $\begin{array}{c}\text { Stations X } \\
\text { Seasons }\end{array}$ & 4 & 2374.95 & $<0.00$ \\
\hline & $\begin{array}{l}\text { Overall } \\
\text { Means }\end{array}$ & $4.71 \pm 0.84$ & $7.09 \pm 1.20$ & $3.32 \pm 1.57$ & $5.05 \pm 1.99$ & - & - & - & & & & \\
\hline \multirow[t]{4}{*}{ Lead } & Autumn & $65.48 \pm 0.19^{\text {ay }}$ & $65.56 \pm 0.29^{\text {ay }}$ & $65.46 \pm 0.24^{\mathrm{ay}}$ & $65.50 \pm 0.23$ & & & & Stations & 2 & 2061.63 & $<0.00$ \\
\hline & Winter & $40.40 \pm 0.36^{\mathrm{bz}}$ & $41.51 \pm 0.22^{\mathrm{az}}$ & $40.59 \pm 0.32^{\mathrm{bz}}$ & $40.84 \pm 0.57$ & & & & Seasons & 2 & 186240.07 & $<0.00$ \\
\hline & Spring & $78.53 \pm 0.28^{\mathrm{cx}}$ & $91.52 \pm 0.20^{\mathrm{ax}}$ & $86.42 \pm 0.29^{\mathrm{bx}}$ & $85.45 \pm 5.39$ & & & & $\begin{array}{c}\text { Stations x } \\
\text { Seasons }\end{array}$ & 4 & 1601.21 & $<0.00$ \\
\hline & $\begin{array}{l}\text { Overall } \\
\text { Means }\end{array}$ & $61.47 \pm 16.12$ & $66.15 \pm 20.75$ & $64.15 \pm 19.09$ & $63.93 \pm 18.62$ & 35 & 31 & 42 & & & & \\
\hline
\end{tabular}

* TEL: Threshold effect level; LEL: Lowest effect level; MET: Minimal effect threshold (MacDonald et al. 2000)

The different letters (a, b, and c) in the same row, show significant difference among stations (I, II, and III) for the same heavy metal and season ( $p<0.05)$

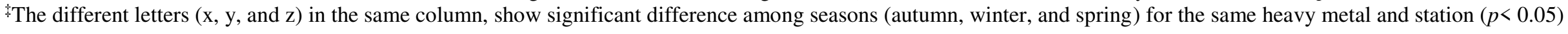


Table 3: Heavy metal concentrations (Mean $\pm \mathrm{SD} ; \mu \mathrm{g} \mathrm{g}{ }^{-1}$ ) at three sampling stations (I, II \& III) in the plankton of Punjnad Headworks

\begin{tabular}{|c|c|c|c|c|c|c|c|c|c|}
\hline \multirow[b]{2}{*}{ Heavy Metals } & \multirow[b]{2}{*}{ Seasons } & \multicolumn{4}{|c|}{ Sampling Stations } & \multicolumn{4}{|c|}{ ANOVA } \\
\hline & & I & II & III & Overall Means & Source of variance & $d f$ & $F$-value & $P$-value \\
\hline \multirow[t]{4}{*}{ Aluminum } & Autumn & $350.25 \pm 0.77^{b \uparrow x *}$ & $341.51 \pm 1.12^{\mathrm{cx}}$ & $355.42 \pm 1.04^{\mathrm{ax}}$ & $349.06 \pm 5.92$ & Stations & 2 & 753.67 & $<0.00$ \\
\hline & Winter & $286.68 \pm 0.67^{\mathrm{bz}}$ & $283.86 \pm 1.62^{\mathrm{cz}}$ & $293.87 \pm 0.77^{\mathrm{az}}$ & $287.96 \pm 4.18$ & Seasons & 2 & 25553.67 & $<0.00$ \\
\hline & Spring & $308.71 \pm 0.95^{\text {by }}$ & $303.48 \pm 1.06^{\mathrm{cy}}$ & $312.17 \pm 0.77^{\text {ay }}$ & $308.12 \pm 3.75$ & Stations x Seasons & 4 & 28.32 & $<0.00$ \\
\hline & Overall Means & $315.21 \pm 26.87$ & $309.62 \pm 24.42$ & $320.31 \pm 26.49$ & $315.05 \pm 25.99$ & & & & \\
\hline \multirow[t]{4}{*}{ Arsenic } & Autumn & $31.46 \pm 0.02^{\text {ay }}$ & $25.04 \pm 0.02^{\mathrm{cy}}$ & $27.40 \pm 0.02^{\text {by }}$ & $27.97 \pm 2.70$ & Stations & 2 & 735346.95 & $<0.00$ \\
\hline & Winter & $23.60 \pm 0.02^{\mathrm{az}}$ & $17.89 \pm 0.02^{\mathrm{cz}}$ & $21.40 \pm 0.02^{\mathrm{bz}}$ & $21.05 \pm 2.41$ & Seasons & 2 & 1650408.99 & $<0.00$ \\
\hline & Spring & $33.94 \pm 0.02^{\mathrm{ax}}$ & $26.95 \pm 0.02^{\mathrm{cx}}$ & $29.75 \pm 0.02^{b x}$ & $30.22 \pm 2.92$ & Station x Seasons & 4 & 10008.67 & $<0.00$ \\
\hline & Overall Means & $29.67 \pm 4.49$ & $23.29 \pm 3.97$ & $26.27 \pm 3.47$ & $26.41 \pm 4.74$ & & & & \\
\hline \multirow[t]{4}{*}{ Barium } & Autumn & $1.98 \pm 0.01^{\mathrm{az}}$ & $1.17 \pm 0.02^{\mathrm{cz}}$ & $1.78 \pm 0.02^{\mathrm{bz}}$ & $1.64 \pm 0.35$ & Stations & 2 & 20984.12 & $<0.00$ \\
\hline & Winter & $2.87 \pm 0.02^{\text {by }}$ & $2.09 \pm 0.02^{\text {cy }}$ & $3.16 \pm 0.02^{\text {ay }}$ & $2.70 \pm 0.45$ & Seasons & 2 & 125206.95 & $<0.00$ \\
\hline & Spring & $4.04 \pm 0.03^{b x}$ & $3.76 \pm 0.02^{\mathrm{cx}}$ & $5.52 \pm 0.03^{\mathrm{ax}}$ & $4.44 \pm 0.81$ & Stations x Seasons & 4 & 4406.69 & $<0.00$ \\
\hline & Overall Means & $2.95 \pm 0.84$ & $2.34 \pm 1.09$ & $3.50 \pm 1.58$ & $2.93 \pm 1.29$ & & & & \\
\hline \multirow[t]{4}{*}{ Lead } & Autumn & $50.06 \pm 0.77^{\text {ay }}$ & $39.84 \pm 0.63^{\text {by }}$ & $34.22 \pm 0.62^{\mathrm{cy}}$ & $41.38 \pm 6.72$ & Stations & 2 & 3915.87 & $<0.00$ \\
\hline & Winter & $35.02 \pm 0.58^{\mathrm{az}}$ & $27.85 \pm 0.55^{\mathrm{bz}}$ & $23.95 \pm 0.66^{\mathrm{cz}}$ & $28.95 \pm 4.70$ & Seasons & 2 & 6345.09 & $<0.00$ \\
\hline & Spring & $56.17 \pm 0.55^{\mathrm{ax}}$ & $45.60 \pm 0.57^{\mathrm{bx}}$ & $39.78 \pm 0.50^{\mathrm{cx}}$ & $47.19 \pm 6.93$ & Stations x Seasons & 4 & 53.65 & $<0.00$ \\
\hline & Overall Means & $47.09 \pm 9.07$ & $37.77 \pm 7.55$ & $32.65 \pm 6.70$ & $39.17 \pm 9.80$ & & & & \\
\hline
\end{tabular}

The different letters (a, b, and c) in the same row, show significant difference among stations (I, II, and III) for the same heavy metal and season ( $p<0.05$ )

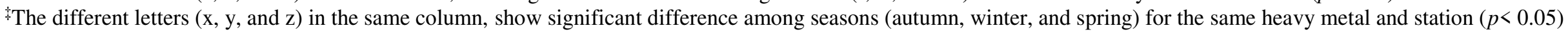


649 Table 4: Correlation matrix between heavy metals concentration in water, sediments and $650 \quad$ plankton at Punjnad Headworks $(n=81)$

\begin{tabular}{llllll}
\hline Source & Heavy Metal & $\mathrm{Al}$ & $\mathrm{As}$ & $\mathrm{Ba}$ & $\mathrm{Pb}$ \\
\hline Water & $\mathrm{Al}$ & 1 & & & \\
& $\mathrm{As}$ & $0.90^{*}$ & 1 & & \\
& $\mathrm{Ba}$ & $0.80^{*}$ & $0.82^{*}$ & 1 & \\
Sediments & $\mathrm{Pb}$ & $0.65^{*}$ & $0.78^{*}$ & $0.75^{*}$ & 1 \\
& $\mathrm{Al}$ & 1 & & & \\
& $\mathrm{As}$ & -0.15 & 1 & & \\
& $\mathrm{Ba}$ & $-0.62^{*}$ & $-0.43^{*}$ & 1 & \\
Plankton & $-0.40^{*}$ & 0.09 & $0.32^{*}$ & 1 \\
& $\mathrm{~Pb}$ & 1 & & & \\
& $\mathrm{Al}$ & $0.52^{*}$ & 1 & & \\
& $\mathrm{As}$ & $-0.43^{*}$ & $0.37^{*}$ & 1 & \\
& $\mathrm{Ba}$ & $0.36^{*}$ & $0.88^{*}$ & $0.23^{*}$ & 1 \\
& $\mathrm{~Pb}$ & & &
\end{tabular}

$651 *$ Significant correlation coefficients at the 0.05 statistical level- 
652 Table 5: Human health risk assessment of heavy metals in water and sediment

\begin{tabular}{lllllllll}
\hline Source & Metal & Exping & Expderm & HQing & HQderm & HI & CR & $\begin{array}{c}\text { TF } \\
\text { (plankton) }\end{array}$ \\
\hline Water & $\mathrm{Pb}$ & 0.71 & $7.09 \mathrm{E}-08$ & 202.50 & $2.02 \mathrm{E}-05$ & 202.5 & $6.02 \mathrm{E}-03$ & 86.30 \\
& $\mathrm{As}$ & $1.23 \mathrm{E}-03$ & $1.23 \mathrm{E}-10$ & 4.11 & $4.11 \mathrm{E}-07$ & 4.11 & $1.85 \mathrm{E}-03$ & 33430.38 \\
& $\mathrm{Al}$ & 0.34 & $3.42 \mathrm{E}-08$ & 0.34 & $3.42 \mathrm{E}-08$ & 0.34 & - & 1436.94 \\
& $\mathrm{Ba}$ & 0.02 & $2.48 \mathrm{E}-09$ & 0.12 & $1.24 \mathrm{E}-08$ & 0.12 & - & 184.39 \\
& $\mathrm{~Pb}$ & $9.98 \mathrm{E}-05$ & $3.49 \mathrm{E}-07$ & 0.03 & 0.02 & 0.05 & $8.48 \mathrm{E}-07$ & $7.30 \mathrm{E}-05$ \\
& $\mathrm{As}$ & $4.87 \mathrm{E}-05$ & $1.70 \mathrm{E}-07$ & 0.16 & $4.11 \mathrm{E}-04$ & 0.16 & & \\
& $\mathrm{Al}$ & $5.78 \mathrm{E}-04$ & $2.02 \mathrm{E}-06$ & $5.78 \mathrm{E}-04$ & $3.42 \mathrm{E}-05$ & $6.12 \mathrm{E}-04$ & - & \\
& $\mathrm{Ba}$ & $7.88 \mathrm{E}-06$ & $2.76 \mathrm{E}-08$ & $3.94 \mathrm{E}-05$ & $1.24 \mathrm{E}-05$ & $5.18 \mathrm{E}-05$ & - & \\
\end{tabular}

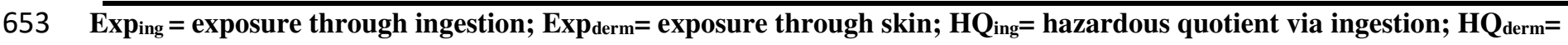

654 hazardous quotient via skin; $\mathbf{H I}=$ hazardous index; $\mathbf{C R}=$ carcinogenic risk; $\mathbf{T F}_{(\text {(lankton) }}=$ heavy metal transfer factor for plankton 


\section{$655 \quad$ Figure Legends}

656 Fig. 1 Geological map of Punjnad Headworks (2856'59.99" N, 70²9'59.99" E) near Uch Sharif.

657 The doubled dotted lines show the Punjnad Headworks bridge. Doubled Solid lines represent 658 canals from Headworks. Square shape markers indicate the sampling stations selected at different 659 locations for taking samples from water, bed sediments and planktons. 


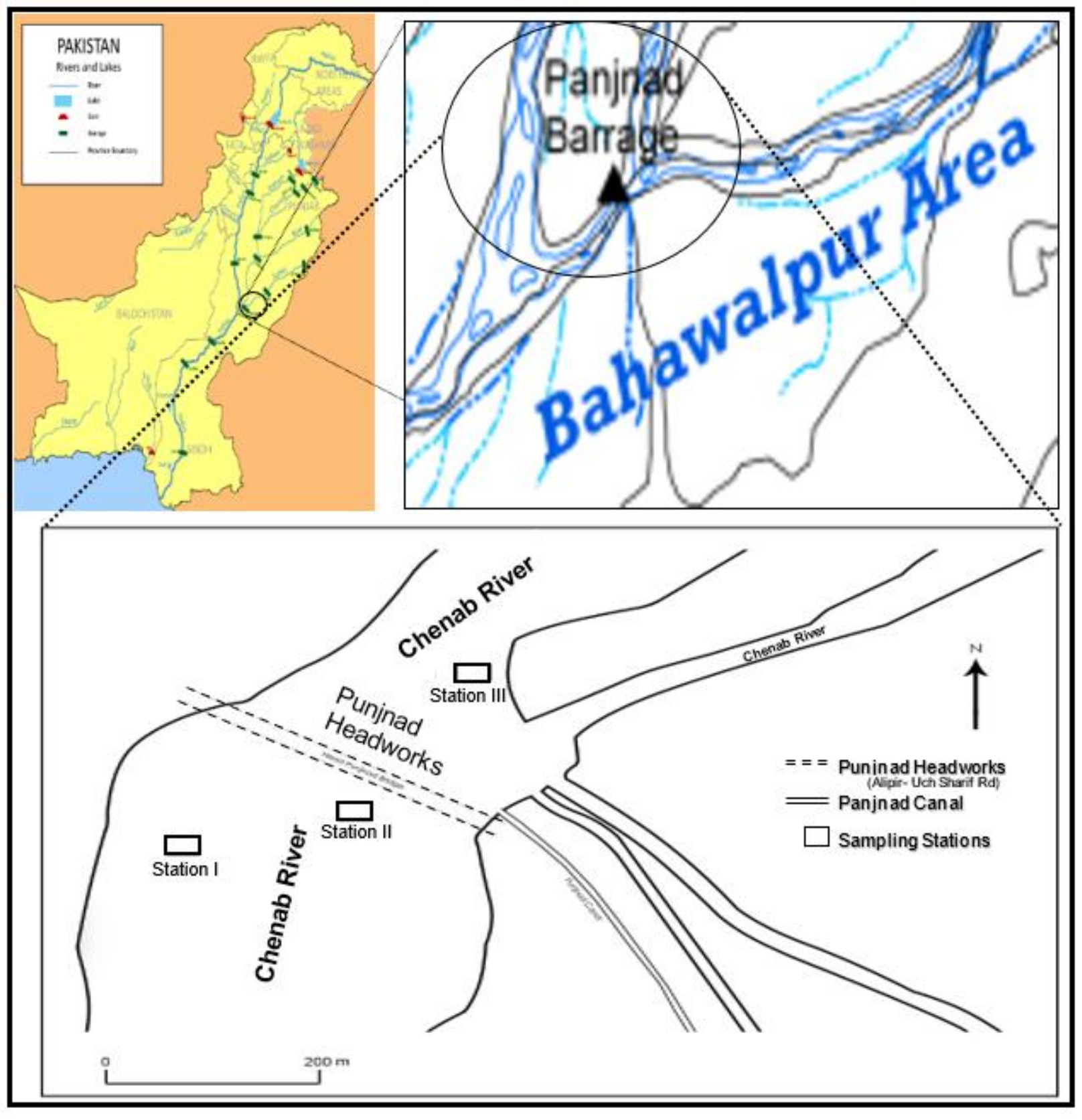

